\title{
BOOK REVIEW \\ Menilik Keistimewaan Penciptaan Manusia Dalam Islam
}

\author{
Ahmad Masrur Firosad \\ (Peneliti Magistra Indonesia. Email: afirosad@gmail.com)

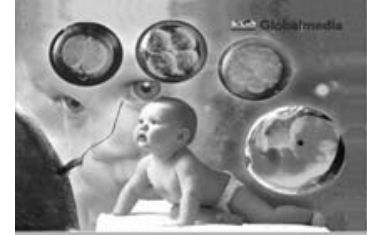 \\ KEAJAIBAN \\ PENCIPTAAN \\ MANUSIA \\ HARUN YAHYA \\ (2) \\ Judul: Keajaiban Penciptaan Manusia \\ Judul Asli: The Miracle of The Creation of The Human Being \\ Penulis: Harun Yahya \\ Alih Bahasa: Ahmad Sahal Hasan \\ Halaman: iii + 178 halaman \\ Penerbit: PT. Globalmedia Cipta Publishing Jakarta \\ Cetakan: Pertama
}

Tahun: Dzulhijjah 1423 H, Februari 2003 M

\section{TUBUH SEBAGAI STRUKTUR SEMPURNA BAGI MANUSIA}

Buku ini di awali oleh penulisnya Harun Yahya dengan bahasan mengenai kesempurnaan tubuh manusia yang diibaratkan sebagai mesin mempunyai struktur paling kompleks di muka bumi ini. Mesin kompleks ini dapat dipergunakan untuk melihat, mendengar, bernafas, berjalan, berlari cepat, dan menikmati kelezatan rasa sepanjang hayat. Ia memiliki sistem dan pengorganisasian yang sangat rumit. Hal ini bisa dilihat pada susunan anatomi dan aktivitas tulang, otot, pembuluh darah, dan seluruh organ yang ada dalam tubuh. Bila kita perhatikan lebih dalam sistem dan pengorganisasian dalam tubuh kita, maka kita akan selalu menemukan berbagai hal menakjubkan. Bayangkan tubuh kita yang terdiri dari bagian-bagian berbeda tersebut ternyata terbentuk dari bagian terkecil yang sama yaitu sel. Tubuh kita terdiri atas sel-sel berukuran hampir 1/1000 mm3 (seperseribu milimeter kubik). Dari kumpulan sel 
tersebut akan terbentuk tulang, syaraf, hati, bagian dalam lambung, kulit, dan lapisan-lapisan lensa mata kita. Masing-masing sel ini memiliki sifat dan karakter khusus dan penting. Baik dalam hal bentuk, ukuran, maupun jumlahnya. Bagaimana dan kapan sel-sel ini hadir dalam kehidupan kita? Jawaban pertanyaan ini akan menggiring kita menuju dunia penuh keajaiban di setiap detiknya. Ternyata sel-sel tubuh kita yang jumlahnya mencapai 100 triliun ini berkembang dan berawal hanya dari satu sel saja. Sel ini memiliki sifat dan karakter sama dengan sel-sel tubuh kita yang lainnya ini adalah hasil peleburan antara sel telur ibu dengan sel sperma ayah.

Dalam Al Qur'an disebutkan bahwa pada keajaiban penciptaan langit dan bumi, serta makhluk hidup ciptaan-Nya terdapat banyak bukti tentang wujud dan keagungan-Nya. Diantara bukti terpenting tentang wujud dan kebesaran-Nya ialah keajaiban penciptaan manusia itu sendiri. Banyak ayat-ayat Al Qur'an yang mengarahkan manusia untuk berpikir dan merenungkan penciptaan dirinya. Bagaimana ia ada dan diciptakan, juga menginformasikan tahap-tahap penciptaan itu dengan rinci Ternyata awal kehidupan dari tubuh manusia yang terdiri dari $60-70 \mathrm{Kg}$ daging dan tulang ini, hanyalah berasal dari setetes air. Proses perkembangan tubuh manusia ini berlangsung sangat kompleks, di mana akhirnya tubuh tersebut memiliki akal, pendengaran dan penglihatan. Ini adalah fenomena yang mencengangkan dan luar biasa. Tak diragukan lagi bahwa perubahan dan perkembangan seperti itu mustahil terjadi begitu saja sebagai hasil sebuah proses kebetulan. Lebih tepat ia merupakan proses penciptaan yang terencana dan sangat sempurna.
Buku ini akan menjelaskan keajaiban penciptaan manusia secara rinci. Sebuah keajaiban yang terus berlangsung dan berulang, serta dialami oleh setiap manusia di bumi ini.

Penting untuk dijelaskan bahwa penjelasan dalam buku ini hanyalah bagian kecil dari seluruh keajaiban penciptaan manusia. Namun hal ini cukup bagi manusia untuk mengetahui bahwa di sana ada kekuasaan Allah yang tak terbatas dan ilmu-Nya yang tak terhingga meliputi seluruh alam semesta, agar manusia selalu ingat bahwa Dialah sebaik-baik pencipta.

\section{Keajaiban Sistem Pembentuk Manusia}

Manusia tidak mungkin dapat mempertahankan kelangsungan hidupnya di muka bumi ini tanpa melalui proses yang sangat kompleks dalam sistem reproduksinya. Sistem reproduksi yang ada pada tubuh laki-laki dan perempuan masing-masing memiliki alat-alat reproduksi dan fungsi yang berbeda. Keduanya saling melengkapi satu sama lain dalam sebuah proses yang sangat kompleks namun harmonis, dalam sebuah sistem yang sangat sempurna. Hasilnya adalah kehadiran makhluk baru ke dunia ini. Sungguh, pembentukan manusia dan penciptaannya dari dua orang manusia yang berbeda jasadnya adalah salah satu keajaiaban yang nyata, yaitu keajaiban penciptaan manusia. Untuk terjadinya proses menakjubkan ini, berbagai persiapan penting telah berlangsung di dalam tubuh manusia selama beberapa tahun. Bermula dari berubahnya sel-sel reproduksi dalam tubuh lakilaki dan perempuan menuju tahap pematangan. Saat kesempurnaan proses pematangan ini dikenal dengan masa baligh atau puber. Sistem yang berperan dalam keberhasilan 
proses hubungan antar sel ini adalah sistem hormonal yang diatur dan dikendalikan oleh otak.

Allah SWT telah menjadikan seluruh aktivitas perkembangan dan pematangan tubuh manusia berada di bawah sistem yang dikendalikan otak. Otak akan menyeleksi seluruh pesan dari semua anggota tubuh yang sampai kepadanya, lalu mengirimkan respon yang paling tepat dan cepat menuju tempat yang membutuhkannya. Semua proses seleksi dan komunikasi ini menggunakan sistem hormonal. Allah SWT telah menciptakan sistem jaringan komunikasi yang sangat sempurna. Hormon-hormon itu mengirim pesan ke otak, lalu ia mengirimkan perintah yang berasal dari otak kepada sel-sel yang berkepentingan, seperti tukang pos yang berkeliling kota mengantarkan surat ke alamat yang tepat. Begitulah yang terjadi pada semua efektifitas kegiatan penting dalam tubuh manusia. Namun kita tidak boleh lupa bahwa dalam menentukan arah, mengenal pesan yang akan ia bawa, dan kepada siapa pesan itu ditujukan, hormon ini tidak memiliki kesadaran dan perasaan seperti yang kita miliki, tidak mendapat pelatihan apa pun, dan tidak memiliki pengalaman ditahuntahun sebelumnya. Hormon adalah struktur atau senyawa yang sangat kompleks yang hanya bisa digambarkan dengan persamaan-persamaan dan lambang (rumus) kimia yang sangat rumit. Melalui pesan yang akan dibawanya, hormon mampu mengenali sel-sel yang ditujunya. Hormon mampu melakukan perjalanannya dalam kegelapan di dalam tubuh (kerja ini hanya dapat dilihat dengan proses yang diperbesar beberapa miliar kali) tanpa sedikit pun tersesat.

Selanjutnya hormon menunaikan tugasnya dengan sebaik-baiknya tanpa kesalahan. Semua ini adalah pekerjaan yang luar biasa dan sangat menakjubkan. Semua ini sudah cukup menjadi bukti betapa sempurnanya sistem yang diciptakan Allah dalam tubuh manusia. Efektivitas kerja sistem hormonal ini biasanya dimulai di dalam tubuh sejak manusia masih menjadi janin di perut ibunya dan terus berlangsung hingga ia wafat. Kerja alat-alat reproduksi dan anggota tubuh yang terlibat sangat dipengaruhi oleh hormon. Rangsangan hormon yang berhubungan dengan alat reproduksi baru dimulai pada masa baligh, ini berbeda dengan hormon yang lain. Pada masa baligh inilah pengatur sistem hormonal dalam otak, yaitu hipotalamus, mengirimkan perintah kepada hipofisis (kelenjar yang menggantung dibawah hipofisis) agar memberikan rangsangan kepada alat-alat reproduksi. Ada keajaiban lain yang perlu diperhatikan di sini: ternyata hipotalamus sangat mengetahui apa yang terjadi pada tubuh manusia, ia tahu kapan sistem dan alat reproduksi telah sempurna dan siap bekerja. Dengan kata lain ia bekerja menghitung umur manusia. Ketika ia mengetahui bahwa tubuh manusia telah mencapai masa baligh, ia segera memberikan perintah penting kepada alat-alat reproduksi melalui hormon-hormon reproduksi dalam waktu sangat singkat. Dengan cara ini, kelestarian manusia dapat dijaga. Semua itu tidak hanya dilakukan hipotalamus pada satu tubuh saja. Pekerjaan yang rumit dan sempurna ini telah berlangsung pada bermiliar-miliar manusia normal yang ada saat ini, dan yang hidup di masa lalu

\section{Prajurit Sempurna Yang Menuju Sasaran Dengan Tepat}

Penulis buku ini harun yahya mengajak kita untuk mencoba berimajinasi sambil 
membayangkan sebuah pasukan besar yang terdiri dari jutaan personil menuju sebuah sasaran. Tidak peduli seberapa jauh jarak yang harus ditempuhnya, tantangan besar, dan bahaya mematikan yang akan dihadapinya dalam perjalanan menuju sasaran tersebut. Bayangkan bahwa panjang perjalanan ini lebih dari ratusan ribu kali panjang tubuh prajurit. Dalam perjalanan panjang ini pastilah pasukan itu membutuhkan bantuan logistik, petunjuk, dan persiapan tambahan lainnya. Pasukan yang berjumlah 300 juta personel ini terdapat dalam tubuh laki-laki, dan personilnya adalah para sel sperma yang panjangnya mencapai seperseratus milimeter dan harus melalui perjalanan panjang menuju sasarannya, yaitu sel telur. Seribu dari 300 juta sel sperma ini berhasil mencapai sel telur, tetapi hanya satu sel saja yang memenangkan pertarungan ini dan membuahi sel telur. Sebelum mengikuti perlombaan ini, sel sperma harus melalui tahaptahap pematangan yang diawali dengan keluarnya sel ini menuju sebuah perjalanan panjang melalui alat reproduksi laki-laki.

Ada banyak persiapan yang membantu proses pematangan sel sperma ini. Untuk membuahi sel telur perlu dipersiapkan kurang lebih 200-300 juta sel sperma. Jumlah yang besar ini dibutuhkan karena sebagian besarnya akan mati dalam perjalanan, dan relatif sedikit yang berhasil menuju sel telur. Oleh karena itu jumlah yang besar ini menjaga sperma dari kegagalan membuahinya. Produksi sel sperma terjadi pada alat reproduksi laki-laki yang disebut testis. Sel sperma yang diproduksi di dua buah testis ini melalui berbagai proses perkembangan dan harus terhindarkan dari suhu yang tinggi. Dengan kata lain tempat produksinya harus cukup dingin, padahal suhu normal tubuh manusia mencapai
37 derajat Celcius. Jadi jika testis berada dalam tubuh manusia maka sel sperma tidak akan dapat diproduksi. Oleh karena itu, testis harus berada di bagian luar tubuh. Testis memiliki program khusus yang memungkinkan-nya dapat memproduksi sel sperma. Testis terdiri dari tabung-tabung kecil. Tabung-tabung ini memiliki daya tampung yang memungkinkan produksi sperma dengan cepat serta memudahkan penyimpanannya. Kegiatan produksi sperma yang cepat dan proses penyimpanannya yang mudah sangatlah penting. Ini karena jumlah sperma yang dibutuhkan untuk membuahi sebuah sel telur sangatlah besar: antara 200-300 juta sel sperma. Sungguh menakjubkan, cairan yang dirangsang oleh kelenjar prostat ini mampu mengetahui tubuh lakilaki dan perempuan sekaligus secara sangat rinci. Ia tahu bahwa berkontraksinya tuba fallopii dalam rahim akan memudahkan pergerakan sperma, untuk itu ia menambahkan prostaglandin ke dalam tubuh perempuan.

Andaikan kita meminta seorang ahli kimia untuk melakukan semua ini, apa yang akan ia lakukan? Pertama, ia akan meneliti struktur sperma, bagaimana pembuahan terjadi dan apa kondisi yang dibutuhkan pada proses pembuahan. Kemudian ia akan meneliti tubuh wanita, berbagai hormonnya, sel telur, tuba fallopii yang mengantar sel telur sampai rahim. Lalu ia akan meneliti rahim dan sistem syaraf di dalamnya agar dapat diketahui bagaimana proses kontraksinya berlangsung. Kemudian ia akan berusaha menggunakan penelitian yang telah dilakukannya bertahun-tahun untuk mendapatkan zat yang tepat, lalu melakukan uji coba dan riset kepustakaan agar memperoleh komposisi yang tepat dari zat tersebut. 
Ternyata manusia yang memiliki akal dan kecerdasan membutuhkan pengkajian rumit dan mendalam serta memakan waktu bertahun-tahun agar berhasil melakukannya. Proses ini telah dilakukan oleh anggota tubuh manusia yang tak memiliki akal dan perasaan. Tak mungkin kita mengatakan bahwa mereka lebih cerdas dari para pakar kimia sehingga mampu melakukannya sendirian. Cairan dan sel yang diproduksi dalam sistem reproduksi laki-laki dan sistem reproduksi perempuan adalah ciptaan Allah. Sangatlah mustahil kalau sistem yang terintegrasi satu sama lain ini terjadi akibat serangkaian peristiwa "kebetulan". Akal dan sikap objektif kita akan membuat kita tunduk kepada kekuatan dan kekuasaan tak terbatas yang telah menciptakan sistem ini pada bermiliar-miliar manusia sejak dulu, kini, dan di masa mendatang.

\section{Penentuan Jenis Kelamin Anak}

Banyak orang yang meyakini bahwa sel-sel ibu yang menentukan jenis kelamin janin, atau paling tidak menganggap bahwa sel-sel ayah melakukan kerjasama dengan sel-sel ibu untuk menentukannya. Akan tetapi Al Qur'an sejak lebih dari 14 abad yang lalu telah memberikan informasi yang berbeda: jenis kelamin laki-laki atau perempuan ditentukan oleh mani yang dipancarkan ke dalam rahim.

"Dan bahwasanya Dialah yang menciptakan pasangan: laki-laki dan perempuan dari air mani apabila dipancarkan." (Q.S. An-Najm (53): 45).

Kebenaran informasi Al Qur'an ini terbukti secara ilmiah setelah tercapainya kemajuan embriologi dan mikrobiologi. Tenyata jenis kelamin ditentukan oleh sel sperma laki-laki, sedangkan sel telur tidak berperan apa pun di sini. Di antara 46 kromosom, ada 2 kromosom yang menentukan jenis kelamin. Dua kromosom ini pada laki-laki dilambangkan dengan (XY) dan pada perempuan dengan (XX). Kromosom $\mathrm{Y}$ membawa gen laki-laki, sedangkan X membawa gen perempuan. Awal terbentuknya manusia ditandai dengan bertemunya dua kromosom ini. Pada perempuan sel akan membelah menjadi dua sel yang sejenis ketika terjadi ovulasi, keduanya membawa kode X. Sedangkan pembelahan pada laki-laki menghasilkan 2 jenis yang berbeda: $X$ dan Y. Jika kromosom dari perempuan (X) bertemu dengan kromosom laki-laki yang berjenis $\mathrm{X}$ maka jenis kelamin bayi adalah perempuan, tetapi jika bertemu dengan kromosom berjenis Y maka sang anak akan berjenis kelamin laki-laki. Artinya, jenis kelamin anak tergantung jenis sperma yang membuahi sel telur.

\section{RAHIM IBU: TEMPAT TERBAIK DAN TERAMAN BAGI JANIN}

Harun Yahya menjelaskan mengenai bagaimana rahim menjadi tempat terbaik, bahwa rahim adalah anggota tubuh yang berongga memiliki dinding dengan otot yang kuat dan berukuran tidak lebih dari $50 \mathrm{~cm}$. Tentu saja ukuran ini tidak cukup bagi seorang bayi yang terus tumbuh membesar meskipun berbagai persiapan lain telah dilakukan. Untuk itu rahim perlu memperbesar terus-menerus selama masa kehamilan hingga mencapai ukuran $1100 \mathrm{~cm} 3$. Dengan keunikannya ini rahim menjadi tempat paling baik dan aman bagi janin hingga menjadi manusia sempurna yang siap dilahirkan. Lebih dari itu keberadaannya di tengah tulang panggul menjadikan rahim sebagai tempat berlindung 
yang aman bagi zigot selama pertumbuhannya (Guyton \& Hall, 1996).

Dan sesungguhnya Kami telah menciptakan manusia dari sari pati berasal dari tanah. Kemudian Kami jadikan sari pati itu air mani yang disimpan dalam tempat yang kokoh (rahim). (Q.S. Al Muminun (23): 12-13).

Agar kehamilan dapat terus berlangsung dengan sehat dan aman, janin perlu menempati tempat yang sesuai untuknya dan tepat untuk dapat melahirkannya setelah sembilan bulan. Lebih dari itu tempat ini juga harus dekat dengan pembuluhpembuluh darah ibu yang membawa makanan bagi janin. Janin yang berada di tuba fallopii selama 3-4 hari tetap mengarahkan dirinya menuju rahim, seakan-akan ia tahu betul tujuan yang tepat, dan tidak pernah merubah tujuannya. Ia tahu kalau ia menempel di tempat lain ini berarti tamat riwayatnya. Ia terus mencari dan menuju tempat yang memiliki banyak pembuluh darah untuk menempel padanya. Bagaikan benih tanaman yang tumbuh di atas tanah dan akarnya yang semakin menghujam ke dalam tanah, kita menyaksikan janin yang terus berkembang dan terus melekat kuat pada rahim yang memberikan kepadanya suplai makanan.Kemampuan janin memilih tempat yang sesuai merupakan keajaiban tersendiri dari penciptaan manusia.

G. Flanagan dalam bukunya "Beginning $O f$ Life" mengatakan: "Perbuatan kumpulan sel-sel memilih tempat yang tepat dan perencanaannya ke depan adalah hal yang amat menakjubkan." Apa yang disampaikan oleh Flanagan amat penting untuk kita pikirkan. Bayangkan jika kita meletakkan seorang bayi yang baru mulai berjalan di depan bangunan yang besarnya jutaan kali lebih besar dari dirinya, lalu kita biarkan ia menemukan sendiri sebuah ruangan dalam bangunan tersebut yang memenuhi segala kebutuhannya. Sanggupkah bayi tersebut melakukannya? Pasti tidak. Jika bayi yang belum dapat berpikir matang, dan tidak memiliki kemampuan mustahil melakukan hal tersebut, maka segumpal daging berukuran beberapa sentimeter yang berada di kegelapan mustahil pula dapat menemukan tempat yang paling baik baginya. Kita juga mesti ingat bahwa janin tersebut belum menjadi manusia. Ia hanya sekumpulan sel yang tidak memiliki telinga, mata, tangan, kaki dan otak. Tetapi ternyata kita lihat ia mampu memilih tempat yang terbaik baginya (Geraldine Lux Flanagan, 1996).

Keajaiban tidak berhenti hanya di sini. Pada setiap fase kita akan menemukan serangkaian keajaiban satu demi satu. Sampai di sini kami telah menjelaskan bagaimana zigot memperbanyak diri dan menempati posisi terbaiknya. Selanjutnya kita bertanya: Bagaimana kumpulan sel-sel ini kemudian mampu menempel dengan baik pada dinding rahim? Cara yang yang digunakannya untuk menempel pada rahim sangat kompleks dan mengundang kita berpikir. Sel-sel yang berada di lapisan luar janin mengeluarkan enzim hyaluronidase yang berfungsi menghancurkan lapisan asam yang terdiri dari asam hyaluronidat yang terdapat pada dinding rahim. Dengan demikian sel-sel janin dapat menembus lapisan luar rahim, tertanam ke dalamnya, dan menempel dengan kokoh. Janin memerlukan oksigen dan zatzat makanan secara terus menerus agar tetap hidup dan berkembang. Kita melihat bahwa janin yang berasal dari satu sel ini akan mendapatkan semua kebutuhannya dari rahim selama sembilan bulan.

Kemudian air mani itu Kami jadikan segumpal darah ('alaqah), lalu segumpal darah itu Kami 
jadikan segumpal daging (mudghah), dan segumpal daging itu Kami jadikan tulang belulang, lalu tulang belulang itu Kami bungkus dengan daging. Kemudian Kami jadikan dia makhluk yang berbentuk lain. Maka Maha Suci Allah Pencipta Yang Paling Baik. (Al-Müminun (23):14).

\section{Persiapan Untuk Bernafas Yang Pertama Kali}

Bernafas adalah hal terpenting bagi bayi setelah dilahirkan. Kedua paru-parunya yang belum pernah mengenal udara harus dipenuhi udara dan mulai melakukan tugasnya mengambil oksigen, dan ternyata ia berhasil. Padahal saat di dalam rahim, bayi hanya mengambil oksigen dari darah sang ibu. Allah telah menyiapkan segala sesuatu bagi bayi termasuk paruparunya. Dia telah memerintahkan diafragma (batas antara rongga dada dan perut) untuk menyiapkan paru-paru agar dapat berfungsi untuk bernafas. Pada saat usia kehamilan menjelang enam bulan, diafragma mulai melakukan gerakan mengerut dan mengembang, sehingga paruparu memperoleh kesiapan untuk menjalankan tugasnya. Gerakan ini baru akan terus dilakukan tanpa henti setelah kelahiran bayi.

Contoh penyiapan di atas memberitahukan kita bahwa bayi benar-benar berada dalam pemeliharaan khusus yang bukan dilakukan oleh sang ibu sendiri. Karena saat kehamilan, ibu tetap dalam kondisi hidupnya yang biasa. Semua perubahan pada dirinya adalah di luar kehendaknya, tanpa ia dapat ikut campur apalagi mecegahnya. Semuanya terjadi karena rahmat dan karunia Allah, Penguasa Seluruh Alam.

Dengan demikian, segala kebutuhan bayi telah terpenuhi sehingga tidak lagi membuat ibu berpikir bagaimana memenuhinya. Kalupun ia berpikir, ia tak akan mampu membawa sisa makanan janinnya ke dalam ginjal sang ibu untuk dibersihkan, atau mengeluarkannya dari dalam tubuh. Allah, Dialah yang Maha Mengetahui semua kebutuhan setiap bayi, dan Dialah yang telah menciptakan sistem untuk melakukan tugas tersebut. Semua anggota tubuh janin benarbenar telah siap untuk berfungsi di alam dunia. Kedua mata yang belum pernah digunakan, telah dirancang untuk menangkap cahaya di luar, kedua telinga telah dipersiapkan untuk menerima suara, dan semua alat pencernaan makanan telah dipersiapkan untuk menerima dan mengenal berbagai jenis makanan yang masuk ke dalamnya seperti karbohidrat, protein, atau lemak. Tubuh bayi dapat mengetahui bagian tubuh mana yang membutuhkan zat-zat makanan, apa yang dibutuhkan, lalu mengirimnya.

Pandangan dan persiapan ke depan ini tidak mungkin dimiliki dan dilakukan oleh anggota tubuh itu sendiri. Sekali lagi kesiapan sel-sel itu adalah semata karunia Allah yang telah menciptakannya. Pada bulan terakhir kehamilan, tampak jelas pertambahan berat janin yang bertambah. Hal ini disebabkan oleh lapisan lemak berwarna merah tua (kecoklatan) yang terbentuk di belakang leher, sekitar ginjal, dan belakang tulang dada. Lapisan ini berfungsi menjaga suhu bayi pada bulan pertama setelah kelahiran sekaligus sebagai cadangan makanan baginya (Geraldine Lux Flanagan, 1996).

Pada saat yang sama lapisan tipis lemak yang berwarna putih mulai terbentuk di bawah kulit. Pada pembahasan yang lalu, telah disebutkan bahwa sel-sel sistem kekebalan dalam darah ibu tidak diizinkan masuk ke dalam tubuh janin. Janin akan dianggap sebagai benda asing yang pasti akan mendapat penolakkan darinya. Tapi 
situasinya amat berbeda pada bulan kesembilan, di mana antibodi ibu memasuki tubuh janin melalui plasenta. Hal ini disebabkan karena bayi membutuhkan antibodi untuk menghadapi kuman penyakit. Sel-sel antibodi ibu yang sebelumnya tidak dapat masuk, pada bulan terakhir diizinkan masuk untuk melindungi bayi dari penyakit pada awal keberadaannya di dunia. Setelah beberapa bulan, barulah sistem kekebalan bayi memproduksi sel-sel antibodi sendiri, di saat itu sel-sel antibodi yang berasal dari ibu telah habis dan berhenti melakukan tugasnya. Contoh singkat di atas dan contohcontoh lain sebelumnya adalah bukti rancangan sempurna pada penciptaan manusia. Sistem yang sempurna telah dipersiapkan sehingga zat-zat yang membahayakan tidak dapat masuk. Namun tiba-tiba sistem ini berubah sama sekali tatkala kebutuhan menghendakinya dengan sistem lain yang sama sempurnanya. Tentu saja hal ini bukan kehendak sel-sel itu sendiri, tapi ia adalah satu lagi bukti penciptaan (Laurence Pernoud, 1995).

\section{Menyongsong Kehidupan Di Dunia Baru}

Tatkala semua persiapan telah sempurna dan bayi telah siap keluar menuju dunia barunya, Cairan amnion mulai melakukan hal baru yakni membentuk kantung-kantung kecil yang berfungsi memperluas mulut rahim agar mudah dilalui bayi saat kelahiran. Kantung-kantung ini juga mencegah agar bayi tidak mengalami gangguan di rahim. Pada saat awal persalinan, kantungkantung ini pecah dan mengeluarkan cairan yang memperlancar saluran kelahiran sekaligus membuatnya steril dari kuman penyakit (Laurence Pernoud, 1995). Di samping itu bayi juga melakukan gerakan-gerakan bertahap dengan kakinya sehingga kepalanya masuk ke leher rahim, dan ia tak dapat mengeluarkan kepalanya lagi dari sana. Dengan posisi ini persalinan akan menjadi mudah (Geraldine Lux Flanagan, 1996). Namun dari mana bayi yang belum lahir ini mengetahui kondisi dan posisi terbaik kelahirannya? Dari mana ia tahu bahwa telah tiba saatnya untuk keluar dari rahim? Pertanyaan penting ini harus selalu kita ajukan dan pikirkan, agar kita sampai pada kenyataan bahwa bayi mendapat ilham dari Penciptanya, Allah. Tatakala melewati jalan lahir, kepala bayi tidak boleh mengalami cedera. Untuk itu struktur kepalanya harus mendukung. Dan memang tengkorak bayi memiliki struktur khusus yang terdiri dari lima tulang yang salah satunya adalah jaringan elastis dan lunak yang disebut ubun-ubun. Jaringan ini menjamin kepala bayi dapat melewati persalinan tanpa mengalami cedera. Allah, Dialah yang mengatur segalanya: saat awal kehidupan setiap manusia di dunia, dan saat kematiannya. Dan menjadi kewajiban manusia untuk memikirkan penciptaan dirinya sebagai bukti betapa besar kekuasaan-Nya sehingga ia pun akan menjalani hidup sesuai kehendak-Nya demi meraih ridha-Nya.

Hai manusia, jika kamu dalam keraguan tentang
hari kebangkitan, maka ketahuilah sesungguhnya
Kami telah menciptakan kamu dari tanah,
kemudian dari setetes mani, kemudian dari
segumpal darah, kemudian dari segumpal daging
yang sempurna kejadiannya dan yang tidak
sempurna, agar Kami jelaskan kepada kamu,
dan Kami tetapkan dalam rahim apa yang Kami
kehendaki sampai waktu yang sudah ditentukan,
Kemudian Kami keluarkan kamu sebagai bayi,
kemudian berangsur-angsur kamu sampai kepada
kedewasaan, dan di antara kamu ada yang
diwafatkan dan ada pula di antara kamu yang
dipanjangkan umurnya sampai pikun, supaya dia
tidak mengetahui lagi sesuatupun yang dahulunya
telah diketahuinya... (Q.S. Al Hajj (22): 5)

Hai manusia, jika kamu dalam keraguan tentang hari kebangkitan, maka ketahuilah sesungguhnya Kami telah menciptakan kamu dari tanah, kemudian dari setetes mani, kemudian dari segumpal darah, kemudian dari segumpal daging yang sempurna kejadiannya dan yang tidak sempurna, agar Kami jelaskan kepada kamu, dan Kami tetapkan dalam rahim apa yang Kami kehendaki sampai waktu yang sudah ditentukan, Kemudian Kami keluarkan kamu sebagai bayi, kemudian berangsur-angsur kamu sampai kepada kedewasaan, dan di antara kamu ada yang diwafatkan dan ada pula di antara kamu yang tidak mengetahui lagi sesuatupun yang dabulunya telah diketahuinya... (Q.S. Al Hajj (22): 5) 
AIR SUSU IBU: MAKANAN PERTAMA DI ALAM DUNIA

Tubuh bayi yang baru saja membuka matanya di alam dunia harus beradaptasi dengan kehidupan baru. Dan kemampuan beradaptasi ini telah disiapkan sempurna di dalam rahim ibu. Contoh paling jelas tentang hal ini adalah tahap-tahap penyediaan air susu ibu (ASI). Pada dasarnya, produksi ASI berasal dari hormon prolaktin yang diproduksi oleh bagian depan hipofsisa yang ada di otak. Pada fase kehamilan, hormon progesteron dan estrogen yang dihasilkan plasenta menghalangi aktivitas hormon prolaktin dalam memproduksi susu. Namun ketika plasenta keluar bersama kelahiran bayi, hormon prolaktin mulai bekerja. Berkat komunikasi rahasia antar hormon ini, sempurnalah penyediaan ASI bagi bayi. Tentu saja hal ini merupakan keajaiban luar biasa, plasenta yang telah memainkan peran sangat penting saat kehamilan harus keluar pada saatnya untuk memberi kesempatan bagi yang lain untuk berperan. Kita menyaksikan di sini bahwa setiap detik dan detil penciptaan manusia adalah proses yang saling menyempurnakan. Jika yang satu tidak terjadi, yang lain takkan terwujud. Hal ini menunjukkan bahwa manusia diciptakan secara mengagumkan oleh Yang Maha Kuasa. Produksi ASI akan meningkat sesuai kebutuhan bayi terhadapnya. Pada hari-hari pertama setelah kelahiran, 50 gram ASI dihasilkan, dan meningkat menjadi 1 liter pada bulan keenam. Para ahli mengakui tidak mampu membuat air susu yang menyamai kualitas ASI, meskipun mereka telah mengadakan berbagai penelitian. Hal ini disebabkan tidak ada ASI dengan sifat sama yang dimiliki para ibu yang berbeda. Setiap ibu memproduksi ASI sesuai kebutuhan bayinya masing-masing. ASI adalah makanan terbaik bayi yang tidak dapat digantikan fungsinya oleh yang lain. Penelitian menunjukkan bahwa ASI mengandung sel-sel antibodi, hormon, vitamin, dan mineral-mineral lain sesuai kebutuhan bayi yang dilahirkan.

Penggunaan makanan atau susu lain sebagai pengganti ASI tidak akan mampu mencukupi kebutuhan bayi. Makanan lain tidak mengandung zat antibodi yang amat penting bagi kekebalan tubuh bayi. Tatkala kita membandingkan ASI dengan susu sapi, kita menemukan perbedaan yang amat jelas. Susu sapi mengandung zat kasein dalam jumlah besar, yaitu sejenis protein yang ada pada susu yang sulit dicerna. Zat ini sangat sedikit terdapat pada ASI sehingga memudahkan bayi mencernanya. Susunan asam amino kedua susu ini juga berbeda. Hal ini menyebabkan jumlah asam amino yang terdapat pada plasma bayi yang meminum susu sapi meningkat. Sebagian jenis asam amino tertentu meningkat jumlahnya, sedangkan jenis yang lain berkurang. Hal ini menimbulkan pengaruh negatif pada sistem syaraf pusat dan bertambahnya beban kerja ginjal disebabkan meningkatnya protein. Perbedaan lain adalah kandungan laktosa.

Pada ASI kadar laktosa mencapai 7 gram per liter, sedangkan pada susu sapi 4,8 gram per-liter. Partikel-partikel besar pada susu sapi bubuk juga melewati usus halus secara lamban. Pada ASI ini tidak terjadi, sebaliknya laktosa dan air melewati usus halus dan masuk ke usus besar. Dengan demikian usus lebih terjaga kesehatannya dan bakteri yang bermanfaat dapat hidup di sana. Kadar laktosa yang besar pada ASI juga 
mempermudah terbentuknya zat yang amat penting bagi sistem syaraf manusia. Meskipun kandungan lemak dalam ASI dan susu sapi hampir sama, namun jenisnya berbeda. Asam linoleat yang terdapat pada ASI adalah asam lemak satu-satunya yang wajib dikonsumsi oleh bayi. Perbedaan lain adalah kadar garam dan zat-zat lain. Dalam susu sapi terdapat jumlah kalsium dan fosfor dalam jumlah yang banyak, namun perbandingannya tidak seimbang sehingga menimbulkan efek negatif bagi pembaruan dan pembentukan kalsium secara alami dalam tubuh bayi. Oleh karena itu, pemberian susu sapi kepada bayi di harihari pertamanya menyebabkan turunnya kadar kalsium dalam darahnya di samping efek negatif lainnya. Ketika bayi keluar dari dunia yang bebas dari kuman penyakit dalam perut ibunya menuju dunia luar, maka tubuhnya harus bertarung melawan kuman-kuman penyakit yang ada di sekelilingnya. Di antara keistimewaan ASI adalah melindungi bayi dari bahaya penyakit, karena ia mengandung zat antibodi. Pada hari-hari pertama ibu mengeluarkan ASI yang mengandung zat kolostrum. Di dalamnya terdapat sejumlah besar antibodi yang sangat efektif melindungi bayi dari berbagai penyakit. Semakin lama masa menyusui bayi semakin kuat zat antibodi dalam tubuhnya. Hal ini menunjukkan pentingnya ibu menyusui anaknya selama dua tahun penuh. Kenyataan ini telah diungkapkan Al Qur'an lebih dari empat belas abad yang lalu dalam firman-Nya:

"Dan Kami perintahkan kepada manusia berbuat baik kepada dua orang ibu bapaknya, ibunya telah mengandungnya dalam keadaan lemah yang bertambah-tambah dan menyapih setelah menyusuinya selama dua tahun. Bersyukurlah kepada-Ku dan kedua orang tuamu, hanya kepadaKu lah kembalimu." (Q.S. Luqman (31): 14)

\section{KESIMPULAN}

Manusia yang hidup dan akan hidup di permukaan bumi ini awalnya hanyalah sebuah sel sperma yang dipancarkan ke rahim ibu. Dengan sistem khusus yang disiapkan dan diciptakan Allah sel sperma bersatu dengan sel telur dan membentuk sebuah sel hidup yang terus berkembang. Ibu, ayah, saudara, kerabat, kawan atau orang yang tidak dikenal, dan semua yang hidup di dunia saat ini dan dimasa lampau mengalami fase-fase penciptaan yang mengagumkan ini. Setelah melewati masa sekian bulan di mana manusia belum merasakan keberadaannya sama sekali, Allah membentuk tubuhnya dari sebuah sel menjadi manusia sempurna. Merenung dan memikirkan kejadian penciptaan dirinya adalah tugas setiap manusia. Setelah itu hendaklah ia segera memuji serta bersyukur kepada Allah Sang Pencipta. Jangan pernah lupa bahwa Allah yang telah menciptakan Anda, juga mampu membangkitkan Anda kembali dari kematian serta meminta pertanggungjawaban atas segala amal perbuatan Anda. Hal ini adalah mudah bagi Allah. Orang-orang yang melupakan Allah dan mengingkari kehidupan akhirat benarbenar dalam keadaan yang lalai.

\section{KEPUSTAKAAN}

Buku Keajaiban Penciptaan Manusia mencantumkan 73 buku rujukan, 2 majalah/ surat kabar dan 12 jurnal penelitian ilmiah.

\section{TENTANG PENULIS}

Harun Yahya adalah nama pena Adnan Oktar yang lahir di Ankara pada tahun 1956. 
Sebagai seorang da'i dan ilmuwan terkemuka asal Turki, beliau sangat menjunjung tinggi nilai akhlaq dan mengabdikan hidupnya untuk mendakwahkan ajaran agama kepada masyarakat. Adnan Oktar memulai perjuangan intelektualnya pada tahun 1979, yakni ketika menuntut ilmu di Akademi Seni, Universitas Mimar Sinan.

Selama berada kuliah, beliau melakukan pengkajian yang mendalam tentang berbagai filsafat dan ideologi materialistik yang sangat berpengaruh terhadap masyarakat sekitar. Hal ini menjadikan beliau lebih tahu dan paham dibandingkan dengan para pendukung filsafat atau ideologi itu sendiri. Berbekal informasi dan pengetahuan yang mendalam ini, beliau menulis berbagai buku tentang bahaya Darwinisme dan teori evolusi, yang merupakan ancaman terhadap nilai-nilai akhlaq, terhadap dunia; serta buku tentang keruntuhan teori ini oleh ilmu pengetahuan. Majalah ilmiah populer terkenal New Scientist edisi 22 April 2000 menjuluki Adnan Oktar sebagai "pahlawan dunia" yang telah membongkar kebohongan teori evolusi dan mengemukakan fakta adanya penciptaan. Penulis juga telah menghasilkan berbagai karya tentang Zionisme dan Freemasonry, serta ratusan buku yang mengulas masalah akhlaq dalam Al-Qur'an dan bahasan-bahasan lain yang berhubungan dengan akidah.

Buku-buku karya pengarang: 'Tangan Rahasia' di Bosnia, Kebohongan Holocaust, Di Balik Tirai Terorisme, Kartu-Kurdi Israel, Strategi Nasional bagi Turki, Moral Qur'ani: Solusi, Permusuhan Darwin Terhadap Bangsa Turki, Bencana Kemanusiaan Akibat Ulah Darwinisme, Kebohongan Teori Evolusi, BangsaBangsa Yang Diadzab, Nabi Musa, Zaman
Keemasan, Keagungan Warna Ciptaan Allah, Kebesaran Allah di Setiap Sudut Alam Semesta, Hakikat Kehidupan Dunia, Pengakuan Kaum Evolusionis, Kekeliruan Kaum Evolusionis, Sihir Darwinisme, Agama Darwinisme, Al-Qur'an Menuntun Kepada Ilmu Pengetahuan, Asal Usul Kehidupan yang Sesungguhnya, Penciptaan Alam Semesta, Keajaiban Al-Qur'an, Desain Pada Alam, Perilaku Pengorbanan Diri dan Kecerdasan Pada Dunia Hewan, Keabadian Telah Berlangsung, Anakku Darwin Telah Berbohong!, Berakhirnya Darwinisme, Bagaimana Seorang Muslim Berpikir?, Keabadian dan Hakikat Takdir, Jangan Berpura-Pura Tidak Tahu, Misteri DNA, Keajaiban Atom, Keajaiban Sel, Keajaiban Sistem Kekebalan, Keajaiban Mata, Keajaiban Penciptaan Tumbuhan, Keajaiban Laba-Laba, Keajaiban Semut, Keajaiban Nyamuk, Keajaiban Lebah, Keajaiban Biji, Keajaiban Rayap.

Karya penulis dalam bentuk booklet: Misteri Atom, Keruntuhan Teori Evolusi: Fakta Penciptaan, Keruntuhan Materialisme, Berakhirnya Materialisme, Kekeliruan Kaum Evolusionis 1, Kekeliruan Kaum Evolusionis 2, Mikrobiologi Meruntuhkan Teori Evolusi, Fakta Penciptaan, 20 Pertanyaan Yang Meruntuhkan Teori Evolusi, Kebohongan Terbesar Dalam Sejarah Biologi: Darwinisme. Karya-karya pengarang yang berhubungan dengan Al-Qur'an: Pernahkah Anda Berpikir Tentang Kebenaran?, Mengabdi Hanya Kepada Allah, Meninggalkan Masyarakat Jahiliyyah, Surga, Teori Evolusi, Nilai Akhlaq Dalam Al-Qur'an, Ilmu Al-Qur'an, Index Al-Qur'an, Hijrah di Jalan Allah, Sifat Munafiq Dalam Al-Qur'an, Rahasia Orang Munafiq, Nama-Nama Allah Yang Agung, Berdakwah dan Berdebat Dalam Al-Qur'an, Konsep Dasar 
Dalam Al-Qur'an, Jawaban-Jawaban Al-Qur'an, Kematian, Kebangkitan dan Neraka, Perjuangan Para Rasul, Syaitan: Musuh Nyata Manusia, Agama Berhala, Agama Kaum Jahiliyyah, Kesombongan Syaitan, Doa Dalam Al-Qur'an, Urgensi Akal dalam Al-Qur'an, Hari Kebangkitan, Jangan Pernah Lupa, Hukum-Hukum Al-Qur'an yang Diabaikan, Karakter Manusia Dalam Masyarakat Jahiliyyah, Pentingnya Sabar Dalam Al-Qur'an, Pengetahuan Umum Dari Al-Qur'an, Memahami Iman dengan Mudah 1-2-3, Pemikiran Dangkal Kaum Kafir, Iman Yang Sempurna, Sebelum Anda Menyesal, Perkataan Para Rasul, Kasih Sayang Orang Mukmin, Takut Kepada Allah, Mimpi Buruk Kekafiran, Nabi Isa Akan Datang Kembali, Al-Qur'an Memberi Keindahan Pada Kehidupan, Beragam Keindahan Ciptaan Allah 1-2-3-4, Perbuatan Dosa Bernama: 'Mencela', Rahasia Ujian Kehidupan, Hikmah Yang Benar Menurut Al-Qur'an, Perjuangan Melawan Agama Kaum yang Tidak Beragama, Tarbiyyah Nabi Yusuf, Bersekutu dalam Kebaikan, Fitnah Terhadap Umat Islam Sepanjang Sejarah, Urgensi Mengikuti Perkataan yang Baik, Mengapa Menipu Diri Sendiri?, Islam: Agama Mudah, Kegembiraan dan Keteguhan dalam Al-Qur'an, Melihat Kebaikan pada Segala Hal, Bagaimana Orang Bodoh Menafsirkan Al-Qur'an?, Sejumlah Rahasia Al-Qur'an, Keberanian Orang Mukmin. Buku-buku berjudul Kebohongan Teori Evolusi, Bangsa-Bangsa Yang Diadzab, Bagi Kaum yang Berpikir, Hakikat Kehidupan Dunia, Bagaimana Seorang Muslim Berpikir?, Jangan BerpuraPura Tidak Tahu, Keajaiban Semut, Keagungan Warna Ciptaan Allah, Penciptaan Alam Semesta, Allah Dapat Diketahui Melalui Akal, Nilai Akhlaq dalam Al-Qur'an, Konsep Dasar dalam
Al-Qur'an, Pernahkan Anda Berpikir tentang Kebenaran?, Pemikiran Dangkal Kaum Kafir, Urgensi Akal dalam Al-Qur'an, dan Keajaiban DNA telah diterjemahkan ke dalam bahasa Inggris. Keajaiban Semut dan Allah dapat Diketahui Melalui Akal telah diterjemahkan ke dalam bahasa Urdu. Kematian, Kebangkitan dan Neraka telah diterjemahkan ke bahasa Polandia. Bangsa-Bangsa yang Diadzab telah diterjemahkan ke bahasa Portugis, dan telah diterbitkan oleh berbagai penerbitan manca negara.

Banyak karya Harun Yahya yang kini tengah diterjemahkan ke bahasa Inggris, Perancis, Jerman, Itali, Rusia, Spanyol, Arab, Portugis, Albania, Serbo-Kroasia (Bosnia), Polandia, Urdu, Indonesia, Melayu dan Malayalam. Tujuan utama kami adalah untuk menterjemahkan semua buku tersebut ke dalam bahasa Inggris dan berbagai bahasa lainnya pada tahun 2001 dan menyebarkannya ke seluruh penjuru dunia agar bermanfaat bagi semua orang. Dalam semua buku karya pengarang yang menggunakan nama pena Harun Yahya ini, semua topik yang disampaikan sangat sesuai dengan ajaran Al-Qur'an. Bahkan topik-topik yang disampaikan melalui bahasa ilmiah, yang kadang dianggap rumit dan membingungkan, diuraikan dengan sangat lugas dan jelas dalam buku-buku Harun Yahya. Tidaklah mengherankan jika buku-buku tersebut menarik semua orang dari segala umur dan lapisan masyarakat.

Buku-buku yang berhubungan dengan keimanan mendakwahkan tentang keberadaan dan keesaan Allah, dan ditulis dengan tujuan utama menyampaikan Islam kepada mereka yang jauh dari agama dan membuka hati mereka agar menerima kebenaran. Bagi pembaca Muslim, 
buku-buku tersebut berisikan nasehat dan peringatan. Penulis telah menerbitkan karyakaryanya tentang hal-hal pokok yang disebutkan dalam Al-Qur'an agar kaum Muslim dapat meningkatkan ketaqwaan dan kemampuan berpikir mereka secara mendalam.

\section{DAFTAR PUSTAKA}

Flanagan, Geraldine Lux. (1996). Beginning Life. London: A Dorling Kindersley Book.

G.G.Simpson, W.Beck. (1965). An Introduction to Biology. New York: Harcourt Brace and World.

Guyton \& Hall. (1997). Human Physiology and Mechanisms of Disease, (6th. ed.).
Guyton \& Hall. (1996). Tibbi Fizyoloji, (9th ed.). pp 1005, 1017. Istanbul: Nobel T1p Kitabevleri.

Keith L. Moore. (1983). The Developing Human - Clinically Oriented Embryology. Canada: W. B. Saunders Company.

Pernoud, Laurence. (1995). J'attends un enfant. Paris: Pierre Horay.

Tortora, Gerard J. (1998). Introduction to the Human Body The Essentials of Anatomy and Physiology. Biological Science. 
